RESEARCH ARTICLE

\title{
Rotifer community in relation to limnological characteristics of Wular lake in Kashmir Himalaya
}

\author{
Javaid Ahmad Shah ${ }^{1, *}$, Ashok K. Pandit ${ }^{1}$ and G. Mustafa Shah ${ }^{2}$ \\ ${ }^{1}$ Centre of Research for Development (CORD), University of Kashmir, Srinagar-190006, India. \\ ${ }^{2}$ Department of Zoology, University of Kashmir, Srinagar-190006, India.
}

\begin{abstract}
The present study was aimed to assess the impact of physico-chemical parameters of water on the rotifer community in Wular Lake, the largest freshwater lake in the Indian subcontinent. Water samples were collected between September, 2012 to August, 2014 from nine study sites. Rotifers were collected by filtering 100 liters of water through a nylon silk net having 75 meshes/ linear $\mathrm{cm}$ and preserved in $5 \%$ formalin. Rotifers were abundant during summer and lower diversity was observed during the winter. Kaiser-Meyer-Olkin (KMO) and Bartlett's test was also performed to check the significance of the all the variables with the rotifer species. KMO test reflects that the data can be preceded for PCA as the data reflects significant values. The physico-chemical parameters such as water temperature $\left(19.3 \pm 8 \mathrm{C}^{\circ}\right.$ to $\left.23.3 \pm 9.9 \mathrm{C}^{\circ}\right)$, depth $(1.7 \pm 0.8 \mathrm{~m}$ to $4 \pm 1.7 \mathrm{~m}), \mathrm{pH}(7.1 \pm 0.2$ to $7.8 \pm 0.4)$ and total phosphate phosphorus $(201 \pm 86.4$ to $257.3 \pm 119.4$ $\mu \mathrm{g} / \mathrm{l})$ strongly influenced the rotifer community in the lake.
\end{abstract}

Keywords: Rotifera, Brachionidae, eutrophication, Wular lake, Principal component analysis.

\section{INTRODUCTION}

Rotifers in aquatic ecosystems are exposed to many changes in their physical, chemical and biological processes (rate of reproduction, survival etc.) deciding their survival in aquatic ecosystems (King and Serra, 1998). Some of these changes may be comparatively trifling and organisms can acclimatize, or modify their position in the water column, or sometimes alter their behavior as well. Some environmental confrontations are at times so harsh that the individuals or even community get completely distressed. Populations respond both spatially and temporarily when confronted with environmental changes result in variation in number or frequency. Rotifers, act as important food source for large zooplankton and also for higher trophic levels. Some of the wheel animalcule (Rotifers) species involve in the decomposition of soil organic matter and are considered to be an important food link of water ecosystems (Arora and Mehra, 2003). Further, environmental variations are the most crucial factors for any organism living in temperate lakes. Temperature and chemistry of the water are the most outstanding contributors that affect the qualitative and quantitative composition of plankters in aquatic ecosystems. Most of these parameters show seasonal patterns of change within an annual cycle. Any population must adopt broad range of environmental variations to survive.Usually it is found that populations with a generation time of one year or longer either remain or pass through part of the year in a relatively inactive state. Therefore, the lacustrine population confronting several short-lived generations each year are quite different and vary from one system to the other (King, 1972). In such cases, each generation follow a particular succession pattern existing in different environments (Sommer et al., 1986). Across the globe, number of researchers have conducted studies on determining the impacts of physicochemical parameters of water on rotifer communities (May, 1983; Berzins, and Pejler, 1987; Stemberger,1995; Devetter, 1998; Lougheed and Fraser, 1998; Arora and Mehra, 2003; Dias et al., 2014). However, no published work is available on Wular Lake till date. In this backdrop, the present study was undertaken to study to identify environmental factors that affect the rotifer community in Wular Lake, a Ramsar Site of International Importance in Kashmir Himalaya.

\section{MATERIALS AND METHODS}

Water samples were collected between September, 2012 and August, 2014 from nine study sites into clean polyethylene bottles to measure various physico-chemical as well as 
biological parameters. Among the physicochemical parameters, temperature, $\mathrm{pH}$, depth and transparency were determined in situ. The remaining parameters were analyzed following the standards of APHA (1998) and Wetzel and Lichen (2000). For rotifer analysis, samples were collected by filtering 100 liters of water through a net with 75 meshes/ linear $\mathrm{cm}$ and preserved in $5 \%$ formalin. Identification of the taxa were made by using different keys (e.g. Koste, 1978; Edmondson; 1992; Segers, 1995; Sharma and Sharma, 2008). All Statistical analysis like range, standard deviation (SD), Pearson correlation and Principle component analysis) were performed by SPSS version 16 .

\section{STUDY AREA}

Wular Lake is the largest freshwater lake in the Indian sub-continent located in the flood plains of river Jhelum. It is situated towards north -west of Kashmir about $55 \mathrm{~km}$ from Srinagar city.Geographically the lake is situated at an altitude of $1,580 \mathrm{~m}$ (asl) lying between $34^{\circ} 16^{\prime}$ $34^{\circ} 20^{\prime} \mathrm{N}$ latitudes and $74^{\circ} 33^{\prime}-74^{\circ} 44^{\prime} \mathrm{E}$ longitudes. (Figure 1). The oxbow type lake (with a maximum length of $16 \mathrm{~km}$ and breadth of $7.6 \mathrm{~km}$.) is of fluviatile origin, formed by the meandering of river Jhelum, which brings huge quantities of alluvial deposits. The lake has regular inlets and outlet. River Jhelum is the main feeding channel entering the lake basin, through its bifurcation, near Baniyar and Makhdoomyari in the southeast. It is further drained at Ningli (Sopore) in the north-east by the only single outlet in the form of river Jhelum.

The macrophyte dominant lake has a well developed littoral zone while as limnetic zone is poorly developed. Extended littorals, in general, are dominated by reeds like Phragmites australis and Spargamium ramosum besides rooted floating-leaf types Nymphoides peltatum and Trapa natans. The slightly deeper zones has abundant growth of submerged palnts like Ceratophyllum demersum, Myriophyllum spicatum and Potomogeton spp. forming meadows at various places while the littorals towards the northeastern side are densely populated with Salix plantation which is eating the vitals of the lake.

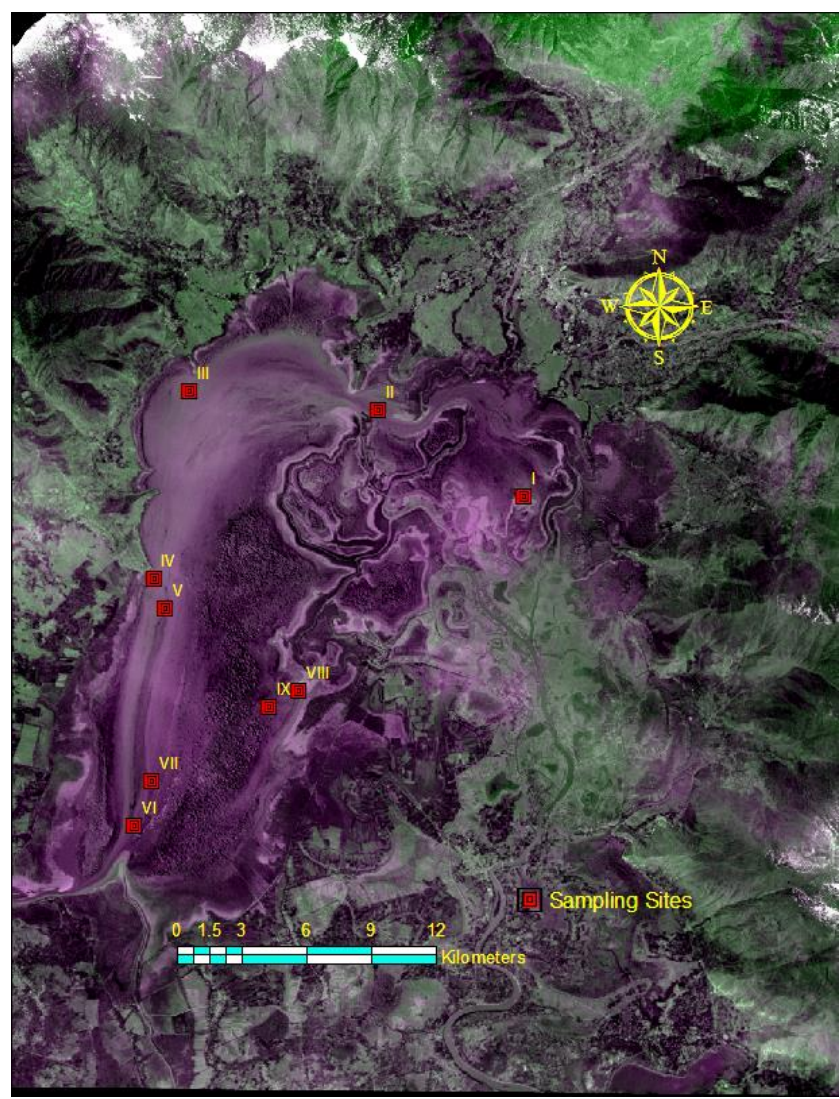

Figure 1: Map of Wular lake highlighting the nine study sites. 


\section{RESULTS AND DISCUSSION}

\section{Physico-chemical parameters of water}

During the study period, water temperature varies from $19.3 \pm 8 \mathrm{C}^{\circ}$ to $23.3 \pm 9.9 \mathrm{C}^{\circ}$ among sampling sites. Water depth ranges from a minimum of $1.7 \pm 0.8 \mathrm{~m}$ to a maximum of $4 \pm 1.7$ $\mathrm{m}$ in sites II and VI, respectively (Table 1). Being a shallow lake, the process of continuous siltation brought from the feeding channels not only leads to shrinkage of the wetlands but also damages the littoral zones there in (Pandit, 1999, 2002; Shah et al., 2013). Further, on the basis of the lowest mean depth ranges, a warning sign of an evolutionary progression, corresponded with higher trophic status as also opined by Rawson (1955) and Hayes (1957) and Pandit (2002). Transparency of water fluctuates spatially and temporarily and recorded lower values at site VIII $(41.4 \pm 17.9)$ and higher at site I (67.4 \pm 31.7$)$. Dissolved oxygen predicted a definite trend registering lower values in summer and higher in winter and ranges from a minimum of $4.64 .6 \pm 1.9 \mathrm{mg} / \mathrm{l}$ at site I to a maximum of $7.1 \pm 3 \mathrm{mg} / \mathrm{l} / \mathrm{at}$ site IX. During the entire study, dissolved oxygen concentration recorded higher values in winter and lower in summer, thereby reflecting an inverse relation with temperature (Gurumayum et al., 2000; Naz and Turkmen, 2005; Idowu, 2013).Total alkalinity ranged from $111 \pm 50.2 \mathrm{mg} / \mathrm{l}$ to $167.6 \pm 79.7 \mathrm{mg} / \mathrm{l}$ at sites III and I respectively. Lower alkalinity values at site III can be attributed to the copious growth of macrophytes (Duggan et al., 1998; 2001) Ammonium- nitrogen and nitrate-nitrogen were lowest at site V $(180.4 \pm 84.3 \mu \mathrm{g} / \mathrm{l})$ and at site VII $(281.6 \pm 130 \mu \mathrm{g} / \mathrm{l})$ respectively. Orthophosphate phosphorus and total phosphorus registered highest values at site IX $(129.4 \pm 57.5 \mu \mathrm{g} / \mathrm{l})$ and at site II $(279 \pm 12(\mu \mathrm{g} / \mathrm{l})$ respectively.

\section{Biological features}

The unpredictability of environmental parameters in terms of spatial and temporalis the main cause for species distribution and their coexistance. Dynamic conditions in the aquatic ecosystems are said to be double edged sword for diversity, either endorsing coexistence via temporal positioning or a parting the species by stochastic extinctions (Shurin et al., 2010). Zooplankton communities respond strongly to any change in the aquatic ecosystem (Gannon and Stemberger, 1978). Jeppesen et al., (2002) opined that the distribution pattern of zooplankton community vary according to physico- chemical parameters of water. There can be a biological equilibrium in aquatic ecosystems with the surrounding medium. However, any environmental factor exceeds species tolerance rangeswill result in the change in community structure (Finlayson and Moser, 1992).

During the entire study period, 26 rotifers represented by 11 families were recorded. Highest number (23) of species were recorded at site II, followed by 18 at site VII, 17 at VI, 15 at IV and VIII, 14 from sites V and VIII and recording the lowest (13) at site III (Table 2). Among the reported families, Brachionidae and Lecanidae were the most dominant, perhaps due to their adaptability to diverse and harsh environmental conditions (Pejler 1977; Shiel et al. 1998; Nandini et al. 2007; George et al. 2011). Segers, (1995) opined that Lecanidae is the second largest family among rotifers with about 160 valid species. Further, Rotifers showed a prominent growth peak in summer in terms of population density in par with high abundance of macrophytes (Ferreiro et al., 2011; Sousa et al., 2011,). Similar summer peaks in terms of density were observed by many workers (Sharma and Srivastav; 1986; Duggen et al., 1998; Bruno et al., 2005; School and Kiss, 2008; Ezhiliet al., 2013). However, some workers have reported population peaks in late summer and early autumn (Whitman et al., 2004; Castro et al., 2005; Paulose and Meheshwari, 2007). Further, Shyeshefer et al., (2008) attributed high rotifer peak in summer to high temperature, long photo period and higher intensity of light.

Principal Component Analysis (PCA) is considered to be an appropriate way to perform data reduction (Fabrigar et al., 1999). This widely-used method reduces a large number of variables to a much smaller number of uncorrelated linear combinations of variables, called principal components that represent the observed data as closely as possible. Generally, the components on steep slope (03) contribute highly while the remaining variables contribute very little for the component analysis (Figure 2). Further, Kaiser (1970) suggested that KMO value should be 0.60 or higher in order to proceed with a factor analysis (Table 3 ). He further opined 0.50 as a cut-off value, and considered desirable of value as 0.8 or higher. In the ordination of physico- chemical variables 
through PCA, water temperature, depth, $\mathrm{pH}$ and total phosphate phosphorus are strongly and positively associated with component 3 confirming their significant impacts on the rotifer community. The remaining parameters (free carbon dioxide, total hardness, magnesium, total alkalinity nitrate nitrogen) showed some impacts but not so strongly as above parameters (Figure 3).Thus, it appears that temporal changes in the rotifer community were greatly influenced by the variables which lie in component 3. It is important to note that dissolved oxygen, transparency, ammonical nitrogen and nitrate nitrogen did not appear to affect the sapatial or temporal distribution of rotifer community. The species which were abundant in summer and autumn were positively associated with $\mathrm{pH}$, water temperature, depth and total phosphate phosphorus and vice versa for winter- spring species (Berzins and Pejler, 1987; Shiel and Koste, 1993). Herrmann (1999) opined that the lakes under eutrophication due to anthropogenic pressures favour higher diversity of rotifers, similar to the observations in the present study during the summer. Pearson correlation matrix predicts that Wheel animalcules maintained significant positive correlation with water temperature $(\mathrm{r}=0.740 ; \mathrm{P}<0.01), \mathrm{pH}(\mathrm{r}=0.626 ; \mathrm{P}$ $<0.01)$, Chloride $(\mathrm{r}=0.610 ; \mathrm{P}<0.01)$, orthophosphate-phosphorus $(\mathrm{r}=0.804 ; \mathrm{P}<0.01)$ and total phosphorus $(\mathrm{r}=0.775 ; \mathrm{P}<0.01)$ while the remaining parameters showed negative correlations (Table 1). Among various parameters, temperature seems to be the foremost important factor that influences the rotifers (Edmondson, 1965). Castro et al., (2005) and Buyurgam et al., (2010) opined that increase in temperature is always associated with high abundance and diversity of rotifers in aquatic ecosystems (Hensen et al., 2007; Shah and Pandit, 2013a). Positive correlation between temperature and the abundance of rotifers was also observed by many workers across the globe (Schöll and Kiss, 2008; Sulehria et al., 2009a; 2009b; Sulehria and Malik, 2012). Wheal animalcules showed a negative correlation with dissolved oxygen in the study. Rutner- Kolisko (1974) stated that rotifers thrive well in low oxygen conditions as majority of them are detritus feeders. Further, Chittapun et al., (2007) found that rotifers maintained negative correlation with dissolved oxygen and total hardness. Our results are in line with Martaugh (1985) who opined that water flies tolerate low dissolved oxygen content (Chittapun et al., 2007; Saler and Sen, 2002; Sulehria and Malik; 2012).Tamas and Horvarth (1978) are in the opinion that there is no influence of chemical ions such as calcium and magnesium on the rotifer density, which is confirmed in the present study.

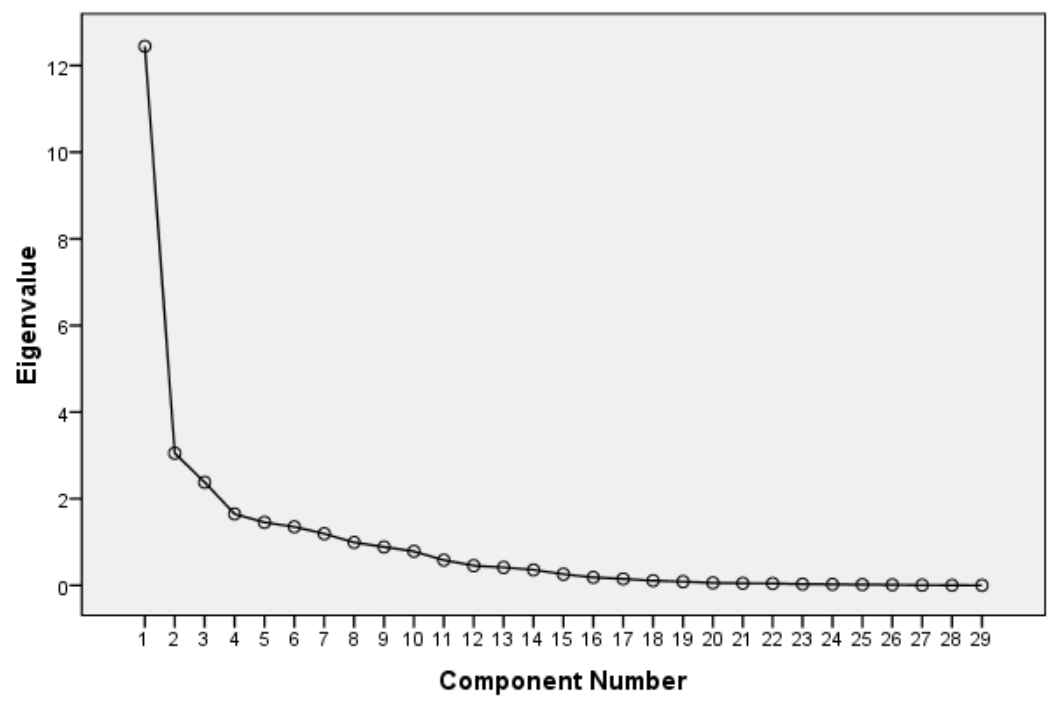

Figure 2: Screen plot of eigenvalues of initial component. 
Table 1: Physico-chemical parameters of water (Range \pm SD) at different sites with Pearson correlation values.

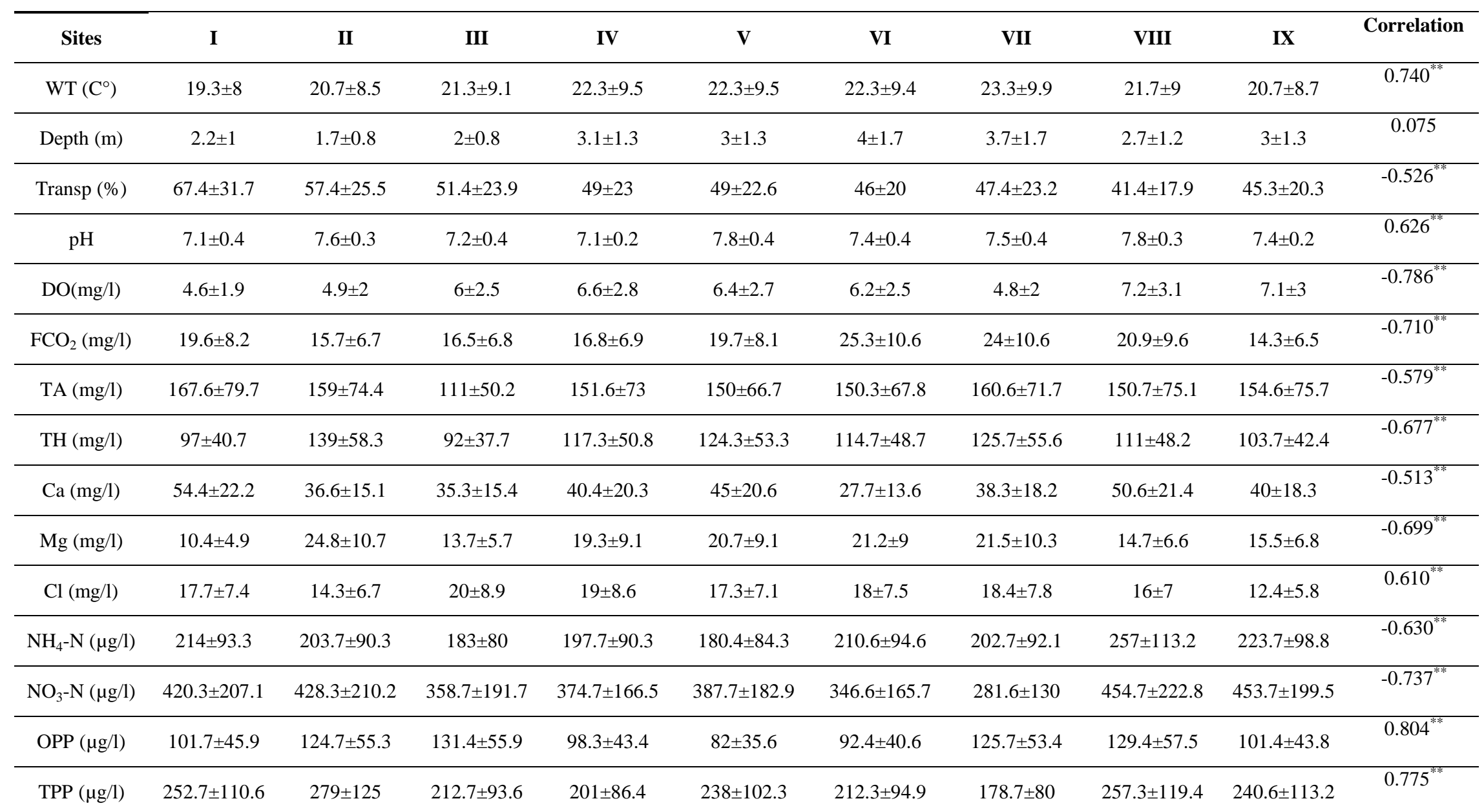

WT= water temperature; $\mathrm{DO}=$ dissolved oxygen; $\mathrm{FCO}_{2}=$ free carbon dioxide; $\mathrm{TA}=$ total alkalinity; $\mathrm{TH}=$ total hardness; $\mathrm{Ca}=$ calcium content; $\mathrm{Mg}=\mathrm{magnesium}$ content; $\mathrm{Cl}=$ chloride,

$\mathrm{NH}_{4}-\mathrm{N}=$ ammonical nitrogen; $\mathrm{NO}_{3}-\mathrm{N}=$ nitrate nitrogen; $\mathrm{OPP}=$ orthophosphate phosphorus $\mathrm{TPP}=$ total phosphorus and correl= Pearson correlation coefficient

**. Correlation is significant at the 0.01 level (2-tailed); *. Correlation is significant at the 0.05 level (2-tailed) 
Table 2: Distribution of rotifers among different sites of Wular lake.

\begin{tabular}{|c|c|c|c|c|c|c|c|c|c|c|c|}
\hline S. No & Rotifera & Abrr. & $\mathrm{I}$ & II & III & IV & $\mathrm{V}$ & VI & VII & VIII & IX \\
\hline \multicolumn{12}{|c|}{ Family Brachionidae } \\
\hline 1 & Anuraeopsis sp. & Anu.sp & + & + & - & + & - & + & + & - & + \\
\hline 2 & $\begin{array}{l}\text { Brachionus bidentata(Anderson, } \\
\text { 1889) }\end{array}$ & B.bid & - & + & + & + & + & + & + & + & + \\
\hline 3 & B. calyciflorus (Ehrenberg, 1838) & B.cal & + & + & + & + & + & + & + & + & - \\
\hline 4 & B. quadridentata (Hermann, 1783) & B.quad & + & + & - & + & - & - & + & - & - \\
\hline 5 & Brachionus sp. & Br. sp & + & + & + & + & + & + & + & + & + \\
\hline 6 & Keratella cochlearis (Gosse, 1851) & K.coc & + & + & - & - & + & + & + & - & + \\
\hline 7 & Keratella hiemalis (Carlin, 1943) & K.hie & + & + & - & - & - & + & + & + & - \\
\hline 8 & $\begin{array}{l}\text { Platyias quadricornis (Ehrenberg, } \\
\text { 1834) }\end{array}$ & P. quad & + & + & + & - & - & - & - & + & - \\
\hline 9 & $\begin{array}{l}\text { Platyias patulus ( O. F. Muller, } \\
\text { 1786) }\end{array}$ & P.pat & + & + & + & + & + & + & + & + & + \\
\hline \multicolumn{12}{|c|}{ Family Lecanidae } \\
\hline 10 & Lecene sp. & Lec.sp & + & + & + & + & + & + & + & + & + \\
\hline 11 & Monostyla bulla (Gosse, 1867) & M.b & + & - & - & + & - & - & - & - & + \\
\hline 12 & Monostyla depressa (Bryce,1891) & M.dep & + & + & + & + & - & - & - & - & + \\
\hline 13 & Monostyla sp. & M.sp & + & + & + & + & + & + & + & + & + \\
\hline \multicolumn{12}{|c|}{ Family Lepadellidae } \\
\hline 14 & $\begin{array}{l}\text { Lepadella patella (O. F. Muller, } \\
1786)\end{array}$ & Lep.pat & + & + & - & - & - & - & + & - & - \\
\hline 15 & Squatinella sp. & Squ.sp & - & - & + & - & + & - & - & - & + \\
\hline 16 & Colurella obtusa (Gosse, 1886) & cl.sp & + & + & + & + & + & + & + & + & + \\
\hline 17 & Paracolurella (Myers, 1936) & P.sp & - & + & - & - & - & - & + & + & - \\
\hline \multicolumn{12}{|c|}{ Family Filiniidae } \\
\hline 18 & Filinia terminalis(Plate, 1886) & F.ter & + & + & - & + & + & + & + & + & + \\
\hline 19 & Filiniasp. & F.sp & + & + & - & - & - & + & + & + & + \\
\hline \multicolumn{12}{|c|}{ Family Mytilinidae } \\
\hline 20 & Mytilina sp. & My.sp & - & + & + & - & + & + & + & + & - \\
\hline \multicolumn{12}{|c|}{ Family Synchaetidae } \\
\hline 21 & Polyarthra vulgaris (Carlin, 1943) & Pol.vul & + & + & - & - & + & + & - & - & - \\
\hline \multicolumn{12}{|c|}{ Family Asplanchnidae } \\
\hline 22 & Asplanchna priodonta (Gosse, 1850) & As.sp & + & + & + & + & + & + & + & + & - \\
\hline \multicolumn{12}{|c|}{ Family Notommatidae } \\
\hline 23 & Cephalodella sp. & Cep.sp & - & + & - & - & + & + & - & - & - \\
\hline \multicolumn{12}{|c|}{ Family Hexarthridae } \\
\hline 24 & Hexarthra mira (Hudson, 1871) & H.mr & - & + & + & - & - & + & + & + & + \\
\hline \multicolumn{12}{|c|}{ Family Scaridiidae } \\
\hline 25 & $\begin{array}{l}\text { Scardium longicaudum (O. F.Muller, } \\
1786 \text { ) }\end{array}$ & S.lo & + & - & - & + & - & - & - & - & - \\
\hline \multicolumn{12}{|c|}{ Family Trichocercidae } \\
\hline \multirow[t]{2}{*}{26} & Trichocerca sp. & Tr.sp & - & + & - & + & - & - & - & - & - \\
\hline & Grand Total & & 19 & 23 & 13 & 15 & 14 & 17 & 18 & 15 & 14 \\
\hline
\end{tabular}


Table 3: KMO and Bartlett's Test.

\begin{tabular}{|c|c|c|}
\hline \multicolumn{2}{|c|}{ Kaiser-Meyer-Olkin Measure of Sampling Adequacy. } & .649 \\
\hline \multirow[t]{3}{*}{ Bartlett's Test of Sphericity } & Approx. Chi-Square & $1.405 \mathrm{E} 3$ \\
\hline & $\mathrm{df}$ & 406 \\
\hline & Sig. & .000 \\
\hline
\end{tabular}

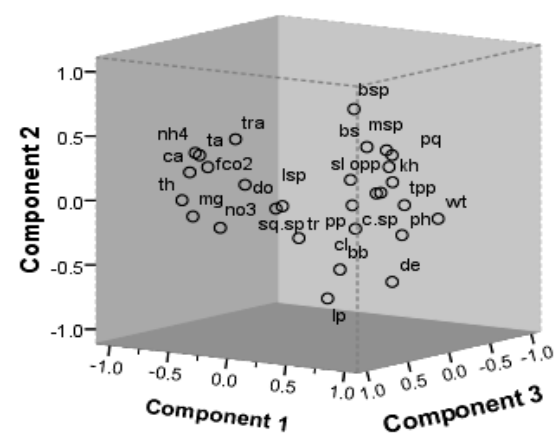

Figure 3: Principal Component analysis ordination plot for rotifer abundance and score of environment variables.

\section{CONCLUSION}

The results can conclude that the rotifers were abundant during warm environmental conditions and lower in colder conditions. Also, the rotifers were abundant in sites having high anthropogenic pressures suggesting that these animalcules act as bioindicators to assess the trophic status of wetlands. Further, the distribution and diversity of rotifers arecontrolled by combination of both physical as well as biological factors.

\section{ACKNOWLEDGMENT}

Thanks are due to the Director, Centre of Research for Development and Head, Environmental Science, University of Kashmir for providing necessary laboratory facilities and also supported our research.

\section{COMPETING INTERESTS}

The authors declare that there is no competing interests.

\section{AUTHORS' CONTRIBUTIONS}

AKP and GMS authors are the research guides of the first author JAS. They have also drafted the sampling design and critically evaluated, coordinated and helped in draft the manuscript. Without their support it was impossible to perform the research. The first author has made collection, identification, analysis and interpretation of the whole data. All authors read and approved the final manuscript.

\section{REFERENCES}

APHA (1998). Standard Methods for Examination of Water and Waste Water $20^{\text {th }}$ Ed American Public Health Association, Washington, DC.

Arora, J. and Mehra, N.K (2003). Species diversity of planktonic and epiphytic rotifers in the back waters of Delhi segment of Yamuna River, with remarks on new records from India. Zoological Studies 42: 239-247.

Berzins, B. and Pejler, B. (1987). Rotifer occurrence in relation to Hydrobiologia 147: 107-116.

Bruno, J.F., Fridley, J.D., Bromberg, K.D. and Bertness, M.D. (2005). Insights into biotic interactions from studies of species invasionsp.13-40In: Species Invasions: Insights into Ecology, Evolution, and Biogeography (DF Sax, JJ Stachowicz, SD and Gaines, eds) Sinauer, Sunderland.

Buyurgan, O., Ahmet, A. and Murat, K. (2010). Zooplankton community of Asartepe Dam Turkish. Journal of Fisheries and Aquatic Sciences 10: 135-138.

Castro, B.B., Antunes, S.C., Pereira, R., Soares, A.M.V.M and Gonçalves, F. (2005). Rotifer community structure in three shallow lakes: Seasonal fluctuations and explanatory factors. Hydrobiologia 543: 221-232.

Chittapun, S., Pholpunthin, P. and Segers, H. (2007). Diversity of rotifer fauna from five coastal peat swamps on Phuket Island, Southern Thailand South Asia 33:383-387. 
Devetter, M. (1998). Influence of environmental factors on the rotifer assemblages in an artificial lake. Hydrobiologia 387/388: 171-178.

Dias J.D., Bonecker, C.C and Miracle, M.R (2014). The rotifer community and its functional role in lakes of a neotropical floodplain. International Review of Hydrobiology (Special Issue: Rotifera XIII) $\quad 99, \quad(1 / 2) \quad 72-83 \quad$ DOI: 101002/iroh201301706.

Duggan, I., Green, J., Thomasson, K. and Shiel, R (1998). Rotifers in relation to littoral ecotone structure in Lake Rotomanuka, North Island. New Zealand Hydrobiologia 387/388: 179-197.

Duggan, I.C., Green, J.D. and Shiel, R.J. (2001). Distribution of rotifers in North Island, New Zealand, and their potential use as indicator of lake trophic state. Hydrobiologia 446: 155-164.

Edmondson, W.T. (1965) Reproductive rates of planktonic rotifers as trelated to food and temperature in nature. Ecological Monographs 35:61-111.

Edmondson W.T. (1992). Freshwater Biology $2^{\text {nd }}$ edition John Wiley and Sons Inc,p 1248.

Ezhili, N., Manikandan, R. and Ilangovan, R. (2013) Diversity and seasonal variation of zooplankton in Ukkadam lake, Coimbatore, Tamil Nadu, India. International Journal of Current Research 5(8): 2091-2094.

Fabrigar, L.R., Wegener, D.T., Mac Callum, R.C. and Strahan, E.J. (1999). Evaluating the use of exploratory factor analysis in psychological research. Psychological Methods 4(3): 272-299.

Ferreiro, N., Feijoó, C., Giorgi, A. and Leggieri, L. (2011). Effects of macrophyte heterogeneity and food availability on structural parameters of the macro invertebratecommunityina Pampean stream. Hydrobiologia 664, 199-211.

Finlayson, C.M and Moser, M. (1992). Wetlands Facts on File, Oxford, 224 pp.

Gannon, J.E and Stemberger, R.S. (1978), Zooplankton (especially crustaceans and rotifers) as indicators of water quality. Transactions of the American Microscopical Society 97:16-35.

George, G., Seeraj C.R. and Roy D.S. (2011). Brachionid rotifer diversity in Andaman waters. Indian Journal of Geo-Marine Sciences 40(3): 454-459.

Gurumahum, S.D., Daimari, P., Goswami, B.S., Sakar, A. and Choudhury, M. (2000). Physico chemical qualities of water and plankton of selected rivers in Meghalaya. Journal Inland Fisheries Society of India 34: 36 - 42.

Hayes, F.R. (1957). On the variation in bottom fauna and fish yield in relation to trophic level and lake dimensions. Journal of the Fisheries Research Board of Canada 14(1): 1-32.

Hessen, D.O., Bakkestuen, V. and Walseng, B. (2007). Energy input and zooplankton species richness Ecography 30: 749-758.
Herrmann, J. (1999). Freshwater biodiversity and Ecosystem functions; ideas and the case River Eman In: Biodiversity in Benthic Ecology (Friberg N and Carl JD eds), Proc Nordic Benth Meeting, Silkeborg, Denmark Tech report, 266.

Idowu, E.O., Ugwumba, A.A.A., Edward, J.B. and Oso, J.A. (2013), Study of the seasonal variation in the physico-chemical parameters of a tropical reservoir Greener. Journal of Physical Sciences 3 (4):142-148.

Jeppesen, E., Jensen, J.P and Søndergaard, M. (2002). Response of phytoplankton, zooplankton and fish to re-oligotrophication: An 11-year study of 23 Danish lakes. Aquatic Ecosystem Health and Management 5: 31-43.

Kaiser, H. (1970). "A second generation little jiffy," Psychometrika 35(4), 401-415.

King, C.E. (1972) Adaptation of rotifers to seasonal variation. Ecology 53:408-418.

King, C.E and Serra, M. (1998). Seasonal variation as a determinant of population structure in rotifers reproducing by cyclical parthenogenesis. Hydrobiologia 387/388: $361-372$

Koste, W. (1978). Rotatoria Borntraeger, Berlin, $673 \mathrm{p}$.

Lougheed, V.L and Chow-Fraser, P. (1998). Factors that regulate the zooplankton community structure of a turbid, hypereutrophic Great Lakes wetland Can J Fish AqSci 55:150-161.

May, L. (1983). Rotifer occurrence in relation to water temperature in Leven, Scotland. Hydrobiologia, 104: 311-315.

Murtaugh, R.A. (1985). The influence of food concentration and feeding rate on the gut residence time of Daphnia. Journal of Plankton Research 7: 415-420.

Nandini, S., Sarma, S.S and Ramirez-Garcia, P. (2007) Seasonal variation of zooplankton from a drinking reservoir (Valle de Bravo) p 4:75-86 In: Mexico in Advances in Fish and Wildlife Ecology and Biology (BL Kauled) Dya Publishing House, Trinagar, Delhi.

Naz M. and Turkmen, M. (2005). Phytoplankton biomass and species composition of Lake Golbasi (Hatay-Turkey). Turkish Journal of Biology 29: 49-56.

Pandit, A.K. (2002). Freshwater biological resources of Kashmir Himalaya p 123-174 In: Natural Resources of Western Himalaya (A K Pandit,ed) Valley Book House, Srinagar-190006, J and K.

Pandit, A.K. (1999). Freshwater Ecosystems of the Himalaya Parthenon Publishing, New York, London.

Paulose. P.V,Meheswari, K. (2007) Seasonal variation in zooplankton community structure of Ramgarahlake, Jaipur. Rajasthan Proceeding of Taal 82-87.

Pejler, B. (1977). On the global distribution of the family Brachionidae (Rotatoria) Archive fur. Hydrobiologia 53: 255-306. 
Pejler, B. (1987). Bruno Bërzins in memoriam 19091985. Hydrobiologia 147:1-2

Rawson, D.S. (1955). Morphometry as a dominant factor in the productivity of large lakes. Verhandlungen des Internationalen Verein Limnologie 12: 164-175.

Ruttner-Kolisko, A. (1974). Planktonic rotifers: Biology and Taxonomy Die Binnengewässer (Suppl) 26: 1-146.

Saler, S. and Sen, D. (2002). Seasonal variation of Rotifera fauna of Cip Dam Lake (Elaziğ-Turkey) Pakistan Journal of Biological Science 5(11): 1274-1276.

Schöll, K. and Kiss, A. (2008). Spatial and temporal distribution patterns of zooplankton assemblages (Rotifera, Cladocera, Copepoda) in the water bodies of the Gemenc floodplain (Duna-Dráva National Park, Hungary). Opusc Zool Budapest 39: 65-76.

Segers, H. (1995). Rotifera II The Lecanidae Guides to the Identification of the Microinvertebrates of the Continental Waters of the World, SPB Academic Publishing, Amsterdam The Netherlands.

Shah, J.A and Pandit, A.K. (2013) .Relation between physico-chemical limnology and crustacean community in Wular lake of Kashmir Himalaya Pakistan. Journal of Biological Science 16 (19): 976-983.

Shah, J.A., Pandit, A.K and Shah, G. Mustafa (2013). Distribution, diversity and abundance of copepod zooplankton of Wular Lake, Kashmir Himalaya. Journal of Ecology and Natural Environment 5(2):24-29.

Sharma, S. and Sharma, B.K (2008). Zooplankton diversity in floodplain lakes of Assam Records of the Zoological Survey of India. Occasional Paper No,290: 1-307.

Sharma, J.P and Srivastava, J.B. (1986). Ecological observations on rotifer fauna of some freshwater ponds of Jammu ( $\mathrm{J}$ and $\mathrm{K})$. India Geobios new reports 5: 6-10.

Shiel, R.J and Koste, W. (1993). Rotifera from Australian inland waters IX Gastropodidae, Synchaetidae, Asplanchinidae (Rotifera Monogononta). Transactions of the Royal Society of South Australia, 17: 111-139.
Shiel, R.J., Green, J.D and Nielsen, D.L. (1998). Floodplain diversity: Why are there so many species? Hydrobiologia, 387/388:39-46 Doi:101023/A:1017056802001.

Shurin, J., Winder, M. and Adrian, R., Others (2010). Environmental stability and lake zooplankton diversity-contrasting effects of chemical and thermal variability. Ecological Letters 13: 453463.

Shyeshefer, S., Mousavi, M. and Shirazi, F. (2008). Ecological study of Rotifera from Kor river, Fars, Iran Journal of Environmental Biology 5: 29-37.

Sousa, W.T.A., Thomaz, S.M. and Murphy, K.J. (2011). Drivers of aquatic macrophyte community structure in a Neotropical riverine lake. Acta Oecologia 37: 462-475.

Stemberger, R.S. (1995). The influence of mixing on rotifer assemblages of Michigan lakes. Hydrobiologia 297: 149-161.

Sulehria, A.Q.K. and Malik, M.A. (2012). Population dynamics of planktonic rotifers in Balloki Headworks. Pakistan Journal of Zoology 44(3): 663-669.

Sulehria, A.Q.K., Qamar M.F., Anjum, R.F., Ejaz, M. and Hussain, A. (2009a). Seasonal fluctuations of rotifers in a fish pond at District Bahawalnagar, Pakistan Biologia 55(1/2):21-28.

Sulehria, A.Q.K., Qamar, M.F, Haider, S., Ejaz, M. and Hussain, A. (2009b). Water quality and rotifer diversity in the fish pond at District Mianwali. Pakistan Biologia (Pakistan) 55(1and2):79-85.

Tamas, G. and Horvarth L. (1978) Growth of cyprinids under optimal zooplankton conditions Bamidgeh 28(3): 50-56.

Wetzel, R.G and Likens, G.E. (2000). Limnological Analyses 3rd ed Verlag, NewYork, Inc NY 429 pp.

Whitman, R., Nevers, B.M., Goodrich, L.M., Murphy, C.P and Davis, M.B. (2004). Characterization of Lake Michigan coastal lakes using zooplankton assemblages. Ecological Indicators 4: 277-286. 